\section{Changing social-class distribution of heart disease}

SIR,-Dr M G Marmot and others (21 October, p 1109) have reported that changes in "consumptions of sugar and, to a lesser extent, milk" may be related to changes in social-class mortality from heart disease (non-valvular and hypertensive)-not in prevalence, as the title of the article might suggest. Their food data from the National Food Survey Committee do not take into account possible socialclass differences and changes in food consumption outside the home. Global epidemiological evidence on total consumptions indicates that milk is more likely than sugar to be aetiologically implicated in ischaemic heart disease. $^{1}$

\section{London NW2}

J J Segall 'Segall, J J, British fournal of Preventive and Social
Medicine, 1977, 31, 81-5.

SIR,-The paper by Dr M G Marmot and others (21 October, p 1109) shows correlations which might account for the continuing change in the social-class distribution of coronary heart disease mortality. The most striking increase is seen since 1951 in men aged 35-44 in classes IV and V. Unfortunately no information is given as regards country of origin or race of the population studied and a large number of classes $I V$ and $V$ in the younger age groups can be expected to be immigrants from overseas and Ireland. If this is so, other, to me more likely, explanations for the changes in the prevalence of coronary heart disease in the different classes are possible than dietary sugar, fibre, or cigarette smoking.

T R E Pilkington

Department of Medicine II,
St George's Hospital Medical School,

London SW 17

\section{Frusemide and renal enzyme excretion}

SIR,-The pages of the $B M \mathcal{F}$ have recently carried articles on the value of the estimation of urinary $N$-acetyl- $\beta$-glucosaminidase (NAG) activity in renal disease, ${ }^{1}$ gentamicin nephrotoxicity, ${ }^{2}$ and renal artery stenosis. ${ }^{3}$ We have carried out an investigation of the effect of the combination of cephaloridine and frusemide on renal function and found a hitherto unreported effect of frusemide on NAG excretion.

Six male volunteers (age 25-34) received single intravenous injections of $1.5 \mathrm{~g}$ cephaloridine with and without $80 \mathrm{mg}$ oral frusemide in a controlled experiment. No abnormal values for indices of renal tolerance were found with cephaloridine alone, but abnormal values were found with frusemide alone. In particular, there was a marked outpouring of NAG in the first $4 \mathrm{~h}$ after dosing with frusemide, as shown in the table. A similar but less marked effect was found with cephaloridine plus frusemide.

Mean urinary $N A G$ excretion $(m I U / h)$ in six volunteers. Numbers of abnormal results $(>120 \mathrm{mIU} / \mathrm{h})$ in parentheses

\begin{tabular}{c|c|c|c|c}
\hline $\begin{array}{c}\text { Period after } \\
\text { administration }\end{array}$ & No drug & $\begin{array}{c}\text { Cephaloridine } \\
\text { alone }\end{array}$ & $\begin{array}{c}\text { Cephaloridine } \\
+ \text { frusemide }\end{array}$ & $\begin{array}{c}\text { Frusemide } \\
\text { alone }\end{array}$ \\
\cline { 2 - 4 } & \begin{tabular}{c|c}
$73(0)$ \\
$2-4 \mathrm{~h}$
\end{tabular} & $\begin{array}{c}53(0) \\
51(0)\end{array}$ & $\begin{array}{c}204(5) \\
75(0)\end{array}$ & $\begin{array}{c}887(6) \\
498(6)\end{array}$
\end{tabular}

There is a wealth of literature to indicate that frusemide is not nephrotoxic, and this finding of raised NAG excretion is presumably related to frusemide's normal action on the renal tubule. It is therefore likely that other drugs may raise enzyme excretion without causing damage. Indeed, Raab and Hohenegger found an increased urinary excretion of leucine aminopeptidase and lactate dehydrogenase in rats given large amounts of penicillin. ${ }^{4}$ They also found urinary excretion of these enzymes to be transiently raised in rats and in man after frusemide administration..$^{5}$

One must therefore be wary of concluding that raised urinary enzyme levels indicate renal damage. Interpretations of "spot" urine samples for NAG estimation in hypertensive patients or in patients with renal disease must include consideration of drug therapy, in particular frusemide usage.

Medical Division Greenford, Middx

Wellwood, J M, et al, British Medical fournal, 1975, 3, 408.

Wellwood, J M, et al, British Medical fournal, 1975, 3, 278. 1, 415.

aab, W, and Hohenegger, M, Clinica Chimica Acta, 1968, 20, 95 $1970,28,61$.

\section{Adverse reactions to intravenous} \section{induction agents}

SIR,-Dr H L Thornton (23 September, p 897) suggests that the role of Cremophor El should be investigated in adverse (anaphylactoid) reactions to the intravenous anaesthetic induction agent Althesin. This powerful detergent is used in other drug formulations, such as Epontol (oily injection of propanidid) and also (but not recommended by the manufacturers) for the solubilisation of diazepam. We agree with Dr Thornton's comments and have ourselves previously drawn attention to possible problems associated with Cremophor El. ${ }^{1-3}$ It is, however, worth pointing out that Cremophor El is not a single well-defined compound but a mixture of some $50-60$ compounds.

While in the dog Cremophor El alone causes direct histamine release, ${ }^{4}$ this does not occur in man and reactions to Cremophor-containing drug formulations may occur from the adjuvant effect of the detergent in presenting pharmacologically active drugs more directly to cells concerned with the reaction mechanisms.

Anaphylactoid response to a variety of intravenous compounds (anaesthetic drugs, muscle relaxants, and plasma expanders) may occur by one or more of several quite distinct mechanisms; these aspects were considered in detail at an international symposium held in Sheffield in June $1978 .^{56}$ The factors predisposing to an anaphylactoid response are equally complex. ${ }^{56}$ Identification of the active
Glaxo-Allenburys Research,

Mansell, M A, et al, British Medical fournal, 1978, agent is extremely difficult except in that small minority of cases where only a single drug has been administered. There is at present no satisfactory single clinical or laboratory procedure for investigating these reactions and few of us working in the field would claim their absolute reliability. We would disagree most strongly with Dr R H Jago (7 October, p 1022) that skin testing proved conclusively that alphaxalone/alphadolone and not Cremophor El were involved in his case. There is no proved correlation between intradermal skin testing and systemic response and such tests can only be regarded as presumptive evidence for the involvement of a particular agent.

\section{JOHN WATKINS}

Department of Immunology,

\section{A MILFORD WARD} J A THORNTON

Department of Anaesthetics,
Hallamshire Hospital Medical
School, School, ' Watkins, J, et al, British fournal of Anaesthesia, 1976,

2 Padfield, A, and Watkins, J, British Medical fournal,

1977, 1, 575.
Watkins, J, Allen, R, and Ward, A M, Lancet, 1978, 2,736

Lorenz, W, Agents and Actions, 1975, 5, 402

Watkins, J, and Clarke, R S J, British fournal of

Anaesthesia. In press.
Adverse Response to Intravenous Drugs, ed J Watkins and A M Ward. London and New York, Academic Press, 1978.

\section{Deputising services}

SIR,-Following our report on a one-in-five sample of nearly 500000 patient contacts with 18 deputising services in 1974-5 (26 February 1977 , p 560) our own university computing service carried out further analyses which uncovered a programming error made by the computer bureau which implemented, under contract, our specified computer system. Regrettably this error led, in our paper, to an exaggeration of the percentage of patients who waited long periods for a deputy visit. The relevant sentences should read:

"Of all patients seen alive by the deputies of the 18 services, $57 \%$ were seen within one hour of contacting the service (ranging from $45 \%$ at one service to $77 \%$ at another) and $1 \%$ [not $7 \%$ as originally suggested] apparently waited four hours or longer as calculated from the recorded time of receipt of the call by the service and the time of the deputy's arrival.... Of patients diagnosed by the deputy, on arrival, as having acute myocardial infarction, less than $1 \%$ [not $5 \%$ ] apparently waited more than four hours."

However, the more recent analyses also show that waiting times were considerably lengthened at holiday times, though it must be remembered that the service deals at such times with higher proportions of non-urgent calls than at other times. Thus in the afternoons (1300-1759) of five days in bank holiday periods $7 \%$ of calls received at all the centres apparently waited four hours or more and the percentage rose to 14 at one centre, which was then handling an hourly average of 20 visits as well as calls not requiring a visit. (All percentages are based on at least 100 records on the computer file.)

Waiting times were no doubt sometimes overestimated at busy periods, however. Congestion of radio space may have prevented the deputy from reporting back to the control centre after every visit and he may sometimes haye forgotten to report his actual time of arrival, so that his time of reporting back to 